\title{
Impacts of Green Office Projects in Thailand: An Evaluation Consistent with Sustainable Development Goals (SDGs)
}

\author{
Sayam Aroonsrimorakot ${ }^{1}$, Meena Laiphrakpam ${ }^{1} \&$ Warit Paisantanakij ${ }^{1}$ \\ ${ }^{1}$ Research Assessment and Certification of Environmental Management, Faculty of Environment and Resource \\ Studies, Mahidol University, Thailand \\ Correspondence: Sayam Aroonsrimorakot, Faculty of Environment and Resource Studies, Mahidol University, \\ Nakhon Pathom, Thailand. E-mail: sayam.aro2560@gmail.com
}

Received: June 11, 2020

doi:10.5539/jsd.v13n4p164
Accepted: July 2, $2020 \quad$ Online Published: July 29, 2020

URL: https://doi.org/10.5539/jsd.v13n4p164

\begin{abstract}
This study aims to evaluate the environmental, economic, and social impacts of a green office project in Thailand, that is consistent with sustainable development goals (SDGs), to analyze and present the result of the study of the environmental, economic, and social impact of green office, and to evaluate satisfaction in the green office project operation. Evaluated the operating steps of green office projects, using new green office evaluation criteria, under Department of Environmental Quality Promotion (DEQP), by collecting preliminary data through questionnaires from 73 agencies, by monitoring and analyzing the project operation of participating organizations to certify as green office standard during 2015 to 2017. Besides, qualitative data were collected through the in-depth interview from 25 representative agencies, selected on the criteria of readiness to provide information and to evaluate their satisfaction in the green office project's operation. The value of the green office project was 299 million Baht for all participant organizations equal to 1.4 million Baht/office/year. And this could be divided into economic compensation, (262.5 million Baht), social compensation (28.5 million Baht), and environmental compensation (7.55 million Baht). Evaluation of satisfaction found that most agencies $(79.45 \%)$ have high satisfaction to certification on the evaluation result of national auditors, benefit on staffs' knowledge, understanding, and observation of the importance of green office operation (86.63\%), and the advantage of green office operation in their office $(90.41 \%)$. The study further suggests that green office projects should be supported as a national policy to all agencies for continuous enhancement or development of the standard, to be an international level according to sustainable development goals (SDGs).
\end{abstract}

Keywords: environmental, economic and social impact, green office project, sustainable development, Thailand

\section{Introduction}

In the recent decades, there has been a growing awareness and concern about global climate change, both developed as well as developing countries (Burch, 2009) According to a recent report, published in the Newspaper of Thailand in 2019, Bangkok's air pollution has reached harmful levels to health, found presence of hazardous substances along with toxic smog up to three times the acceptable standard in some areas (Bangkok Post, 2019). This global climate change and its effect arise from human development activities and energy-related carbon dioxide emissions. This made global environmental scientists, policymakers and academicians to be concerned and search for new developmental steps to reduce $\mathrm{CO}_{2}$ emissions while maintaining sustainable development. Green office is one such step for environmental sustainability and the concept of green office was first defined, developed, and managed by an organization in Finland. According to this organization, green office is a practical step or measure to solve the impact of daily office activities on the environment. So, the green office is an environmental management program for the offices, which can be applied to all kinds of organizations, large or small, public or private, having the ultimate aim of reducing the carbon dioxide or greenhouse gas emission and carbon footprint (World Wide Fund for Nature Finland, 2020). Green's office aims to create an environment, which is healthy to live in for mankind and all living beings along with the conservation of energy and reduction in pollution. With green office, offices' impact on the environment will be reduced, achieved savings economically, and at the same time will lessen the burden on the environment, which will help to retard the effect of climate change in the environment. Sustainable development has been defined in various ways by various scholars. However, the most commonly accepted one is the definition of Brundtland Report (WCED \& Brundtland 1987: 
43) which is defined as "meeting the needs of the present without compromising the ability of future generations to meet their own needs." Opoku \& Ahmed (2013: 141) provide another modified definition as "The adjustment of human behavior to address the needs of the present, without compromising the ability of future generations to meet their own needs". Therefore, impact evaluation of green offices is important for sustainable development, as it is closely associated with economic growth and environmental resource protection for the future.

Department of Environmental Quality Promotion (DEQP) is a state agency that supports and promotes environmental preservation operations. DEQP has foreseen the importance of good environmental management, proceeded eco-friendly production and consumption, and promoted projects with the G-Green concept. Such a project has been proposed with the objectives to initiate organizations' participation for sustainable environmental preservation agencies, including manufacturer, facilitator, and consumer. Due to DEQP's campaign and initiatives, many green projects for environmental sustainability have been formed such as Green Production, Green Hotel, Green Restaurant, Green Natural park, and Green office. This article is one such project on Green Offices. Green offices aim to change personal behavior in the office to combat the present impact of climate change, which increases the global surface temperature due to greenhouse gas emission from human activities (Scafetta, 2010). This has been caused due to human careless activities, causing pollution and environmental degradation, for example, a large quantity of daily waste generated is not suitably managed and discarded inappropriately in unplanned sites, thus resulting in severe environmental hazards (Chowdhury et al., 2014). This environmental degradation is heightened due to the burning of fossil fuels, and wood products to heat buildings, drive vehicles and generate electricity. All these human activities release greenhouse gases into the atmosphere (Sodangi et al., 2011). Therefore, it is necessary to have some defensive measures to solve the mentioned above environmental problems. Some of the steps needed to solve these problems are adopting green practices as reducing energy consumption and initiating eco-friendly activities, such as waste reduction, encouraging to reuse, recycle, stop using hazardous chemicals, support the procurement of eco-friendly product and service (Aroonsrimorakot et al. 2019; Aroonsrimorakot, 2018; Aroonsrimorakot, Phuynongpho \& Athirot, 2019; WWF, 2010; Wichai-utcha \& Chavalparit, 2019). These are the working principles of green office, to initiate and solve greenhouse gases emission and impact on the environment, by encouraging offices to build environmental awareness, promoting ecological and economical sustainability (Aroonsrimorakot \& Sarapirom, 2020) as well as to enhance the potential of all organizations, to be able to manage all the available resources and the environment in the workplaces (Aroonsrimorakot \& Phuynongpho, 2017). Therefore, organizations need to apply green office standards in their offices, to use and practice environmentally friendly resources and activities, owing to the recent trend and impact of environmental changes. The proactive approach to environmental challenges is widely seen in the organization's practice, which seeks to be environmentally friendly, and also aims to improve the financial performance (Varanavicius \& Navikaite, 2015). Consequently, for an organization to be qualified as a green office standard, the offices must have several qualifications as follows: 1) efficient use of energy, water, and other resources; 2) use a renewable resource, such as solar energy; 3 ) reduce pollution and minimize waste and promote reuse and recycle of resources; 4) eco-friendly design, construction, and operation, etc. (WorldGBC, 2016; Hong Kong Green Building Council, 2016). With this promotion of green office principles and aims, DEQP in Thailand has developed, tested and evaluated the result of green office standard application practices in offices of Thailand, to be certified such offices as an eco-friendly pilot office, since the fiscal year 2013. The green office has increased upgrading the eco-friendly office and expanded operations to both government and private offices. Regional and local agencies look after greenhouse gases emission in all sectors and throughout supply chain and consumptions, to lead to eco-friendly sustainable production and consumption. The key to promoting the green office project in Thailand is to operate offices' work process through changing behavioral practices of consumers, both public and private agencies, by focusing on a quantitative measurement associated with personal behavioral changes, to result in an eco-friendly city, and at the same time promoting a sustainable circular economy.

From the green office project operation since the fiscal year 2013 to date, DEQP has compiled participating offices and has evaluated more than 300 office places, but they have not been further monitored and re-evaluated. However, it is important to continue further evaluation of the operating process of each participating office, that apply to obtain a green office standard, so that such offices are consistently related to sustainable development goals of the United Nations. These include evaluation of several government agencies, state enterprises, and private agencies Consequently, the mentioned greenhouse gas emission impacts analysis and evaluation are very important to support the direction, policy, and budget determinations in every green office project's operation of DEQP even in the future too.

\subsection{Research Objectives}

This research paper has the following objectives: 
1) to evaluate the environmental, economic, and social impacts of green office project that is consistent with sustainable development goals (SDGs)

2) to analyze and present the result of the study of the environmental, economic, and social impact of green office

3) to evaluate satisfaction in the continuity of green office operation

\section{Method}

The duration of the performance evaluation of green offices' project operation was from May 15, 2019, to September 14, 2019. The evaluation process was performed with the following activities as:

- Reviewed the operation of green office in the international context, consisting of the operating process of two international organizations, World Wildlife Fund (WWF) and the World Green Building Council (WGBC) as well as green offices' operation in two national organizations, consisting of Singapore and Hongkong. After that, reviewed the criteria of green office's evaluation linked to sustainable development goals (SDGs).

- Evaluate the operating steps of green office projects under DEQP.

The following are the operating steps of the green office project as stated by DEQP as:

1. Establishing the committee to continuously and effectively manage the green office project consisting of green office board, green office team, and green office auditor.

2. Determine the evaluation criteria to be a green office and guidelines to obtain the green office certification

3. Training and giving operational knowledge to a working group of participating agencies.

4. Evaluation and judgment of awarding the agencies according to their performance level.

The evaluation of green office projects was based on certain guidelines. New Green office establishment guidelines of Thailand by DEQP (2018) comprise 6 categories which were then improved in the fiscal year 2019 as shown in Table 1, unlike the old criteria, which consist of 7 categories (DEQP, 2019a).

Table 1. Comparison of old and new green office evaluation criteria

\begin{tabular}{|c|c|c|}
\hline Category & Old criteria & New criteria \\
\hline \multirow[t]{10}{*}{1} & Organization administration & Policies specification, operation planning, and \\
\hline & 1.1 Environmental policies & continuous improvement \\
\hline & 1.2 Issue specification, environmental problem & 1.1 Environmental policies \\
\hline & evaluation, and resources consumption & 1.2 Environmental working group \\
\hline & 1.3 Related laws and regulations & 1.3 Environment and resource issues determination \\
\hline & 1.4 Responsibility and authorities & 1.4 Related laws and regulations \\
\hline & 1.5 Administrative section review & 1.5 Greenhouse gas data \\
\hline & & $\begin{array}{l}\text { 1.6 Project planning leading to continuous } \\
\text { improvement }\end{array}$ \\
\hline & & $\begin{array}{l}\text { 1.7 Green office evaluation within the office (for } \\
\text { age requested agencies) }\end{array}$ \\
\hline & & 1.8 Administrative section review \\
\hline \multirow[t]{6}{*}{2} & Green office operation & Communication and awareness establishment \\
\hline & 2.1 Communication and environmental training & 2.1 Training, knowledge giving, and understanding \\
\hline & 2.2 Conferences and exhibitions arrangement & evaluation \\
\hline & 2.3 Cleanliness and orderliness in the office & 2.2 Campaign and publicity to employee \\
\hline & 2.4 Transportation and traveling & \\
\hline & 2.5 Emergency preparedness and respondents & \\
\hline \multirow[t]{5}{*}{3} & Energy and resource consumption & Energy and resource consumption \\
\hline & 3.1 Energy consumption & 3.1 Energy consumption \\
\hline & 3.2 Water consumption & 3.2 Water consumption \\
\hline & 3.3 Other resources & 3.3 Other resources \\
\hline & & 3.4 Conferences and exhibition arrangement \\
\hline
\end{tabular}


4

Waste management

4.1 Office waste management

4.2 Office wastewater management

5

Environment in office

5.1 Air

5.2 Light

5.3 Sound

5.4 Livability

6

Procurement

6.1 Eco-friendly purchasing

6.2 Eco-friendly hiring

7

Efficiency evaluation and improvement continuously

Waste management

4.1 Waste management

4.2 Wastewater management

Environment and safety

5.1 Air

5.2 Light

5.3 Sound

5.4 Livability

5.5 Emergency preparedness

Procurement

6.1 purchasing

6.2 hiring

7.1 Project and activities leading to improvement continuously

7.2 Greenhouse gas management

Agencies, who are interested in joining the green office project, need to follow the procedure, which consists of 8 steps as:

1. Apply to participate in the project

2. Send the preliminary evaluation document

3. Select the office, if passed preliminary evaluation

4. Training of participant office

5. Visitation for recommendation

6. Evaluate office by the area committee

7. Evaluate the office that passed $90 \%$ of the criteria by the national committee

8. Meeting to summarize the results of the evaluation and to certify the green office.

Finally, the thorough preliminary evaluation document and the green office evaluation criteria will then be promulgated in DEQP's website. The green office evaluation criteria have been made as ISO 14001 Standard by academicians of Mahidol University, DEQP, along with participating experts offering valuable comments, offering suggestions on the criteria for further improvement. The awards for green office are shown in Table 2.

Table 2. Green office awards

\begin{tabular}{ccc}
\hline Green office evaluation criteria & Point level & \\
The best) Gold( & $90 \%$ & Awards \\
Very good) Silver( & $80-89 \%$ \\
Good) Bronze( & $60-79 \%$ \\
Not passed & $<60 \%$ & \\
\hline
\end{tabular}

(DEQP, 2019b) 
- Collected data, monitored, and analyzed the green office project operation to certify the participating organization as green office standard during 2015 and 2017. Altogether, 207 participating agencies/organizations had been certified to have a green office standard, consisting of 1) Natural Resources and Environment Office; 2) Government / Municipal agency and local agencies; 3) Offices of state enterprises; 4) Offices of educational institutions, and 5) Offices of private agencies. Mailed questionnaires were used for collecting data from these 207 certified green office agencies. The questionnaire contained questions to evaluate the continuity and status of operation of the green office, the satisfaction of the agencies to project operation in each step, and the obtained benefit. Altogether 73 agencies (35\%) replied to the questionnaire sent by DEQP.

Target group determination was divided into two levels as:

1. Evaluation of continuity status of operation as a green office project and project satisfaction by sending a preliminary questionnaire to all levels of green office certified agencies.

1) Collection of qualitative data from 25 agencies through in-depth interviewing, to evaluate satisfaction concerning the continuity of green office project operation, also, preliminary data was investigated from the database of the green office project during 2015 -2017. The criteria of selecting agencies for conducting in-depth interviewing was based on the following criteria as consideration in terms of readiness to provide information, by searching from the database of the green office project

2) Area size of agencies

3) Consideration to cover the group of agencies consisting of (1) Offices of Natural Resources and Environment; (2) Government / Municipal Agency and local agencies; (3) Offices of state enterprises; (4) Offices of educational institutions; and (5) Offices of private agencies.

- Consideration from certified green office agencies (only the best level or gold award and very good level or silver award). Both levels, gold, and silver were considered as certified green offices, who were also willing to provide valuable information and understanding of the working process of green office project operation through in-depth interviewing. The project advisors conducted in-depth interviews with 25 representative agencies during the mentioned above fiscal years intending to evaluate satisfaction in the continuity of green office operation by interviewing administrators, working groups, and surveying each organization of the green office's operation. For in-depth interviewing, the target groups were divided according to agencies area-size, into four groups as two agencies having very large areas $\left(>50,000 \mathrm{~m}^{2}\right)$, nine agencies having large areas $\left(12,500 \mathrm{~m}^{2}<\right.$ area $\left.\leq 50,000 \mathrm{~m}^{2}\right)$, nine agencies having medium areas $\left(1,500 \mathrm{~m}^{2}<\right.$ area $\left.\leq 12,500 \mathrm{~m}^{2}\right)$, and five agencies having small areas $\left(<1,500 \mathrm{~m}^{2}\right)$. DEQP has given a gold award or the best level green office certification to 21 agencies and a silver award or very good level to 4 agencies. However, DEQP has not provided the bronze award or good level to agencies as they have insufficient data and continuity of operation.

- Satisfaction evaluation for participating in the green office project. The satisfaction evaluation results were collected from respondents of the preliminary questionnaire, sent to 207 target agencies. It was evaluated from the data of two target groups, namely the green office project operators and administrators of agencies. Evaluations of operator satisfaction comprise two parts as 1) satisfaction to the green office operation steps and 2) satisfaction in the benefits obtained from participating in the project. About satisfaction evaluation of agencies administrators, it was conducted through an inquiry about satisfaction to benefits that agencies receive from participating in the project, including opinions on the agencies' future project-operation. Respondents were given to choose one out of 3 grades, namely high, medium, and low. Details of the questionnaire form can be seen in Tables 3 and 4. 
Table 3. Satisfaction evaluation form of the green office project operation for operators

\begin{tabular}{|c|c|c|c|}
\hline \multirow[t]{2}{*}{ Opinion list } & \multicolumn{3}{|c|}{ Satisfaction Level } \\
\hline & High & Medium & Low \\
\hline \multicolumn{4}{|l|}{ 1. Publicize, invite, and recruit any office to participate in the project } \\
\hline \multicolumn{4}{|l|}{ 2. Office send the document for preliminary self-assessment } \\
\hline \multicolumn{4}{|l|}{ 3. Office join the green office training } \\
\hline \multicolumn{4}{|l|}{4 Visit and recommend improvement according to green office criteria } \\
\hline \multicolumn{4}{|l|}{ 5. Green office evaluation by area/national committee } \\
\hline \multicolumn{4}{|l|}{ 6. National green office auditors issue evaluation result certificate } \\
\hline \multicolumn{4}{|l|}{$\begin{array}{l}\text { 7. The evaluation concluded and give the award to offices that have passed the } \\
\text { green office evaluation test }\end{array}$} \\
\hline \multicolumn{4}{|l|}{ 8. Appropriateness of project duration } \\
\hline \multicolumn{4}{|l|}{ 9.Benefits from participating in the project activities } \\
\hline \multicolumn{4}{|l|}{$\begin{array}{l}\text { - Staffs have increased in knowledge, understanding, and observation of the } \\
\text { importance of green office operation }\end{array}$} \\
\hline \multicolumn{4}{|l|}{ - Staffs have changed their behavior after participating in the project } \\
\hline \multicolumn{4}{|l|}{ - Increase in work efficiency } \\
\hline \multicolumn{4}{|l|}{ - Cost and resource usage in office decrease after participating in the project } \\
\hline \multicolumn{4}{|l|}{ - Promote the quality of life of the employee } \\
\hline \multicolumn{4}{|l|}{$\begin{array}{l}\text { - The office continuously operates activities according to green office guideline in } \\
\text { both present and future }\end{array}$} \\
\hline $\begin{array}{l}\text { - There should be an agency that continuously collects green office improvement } \\
\text { operation data }\end{array}$ & & & \\
\hline
\end{tabular}

Table 4. Satisfaction evaluation form of the green office project operation for administrators

\begin{tabular}{|c|c|c|c|}
\hline \multirow[t]{2}{*}{ Opinion list } & \multicolumn{3}{|c|}{ Satisfaction Level } \\
\hline & High & Medium & Low \\
\hline \multicolumn{4}{|l|}{ 1. You have received the advantage of green office operation in your office } \\
\hline \multicolumn{4}{|l|}{ 2. You agree with green office certification result that your office has received } \\
\hline \multicolumn{4}{|l|}{ 3. You continuously have office improvement policy according to green office } \\
\hline \multicolumn{4}{|l|}{ 4. You desire to renew or enhance the green office certification of your office } \\
\hline $\begin{array}{l}\text { 5. There should be an agency that continuously collects green office improvement } \\
\text { operation data }\end{array}$ & & & \\
\hline
\end{tabular}

- The information through a preliminary questionnaire was obtained from 73 target agencies out of the total 207 agencies administered to 73 and data through in-depth interviewing was obtained from 25 target group agencies. The researcher or adviser then evaluated the collected data for examining the satisfaction of the economic budget of green office operation.

\section{An economic evaluation of Green office's budget}

An economic evaluation of the green office's budget had been considered as an impact assessment method of the green office project operation from 2015 to 2017 . The evaluation result was obtained by examining the operation's list of each office, categorized as new green office evaluation criteria. The guidelines for impact assessment and status of the green office project's budget are illustrated in Figure 1. 


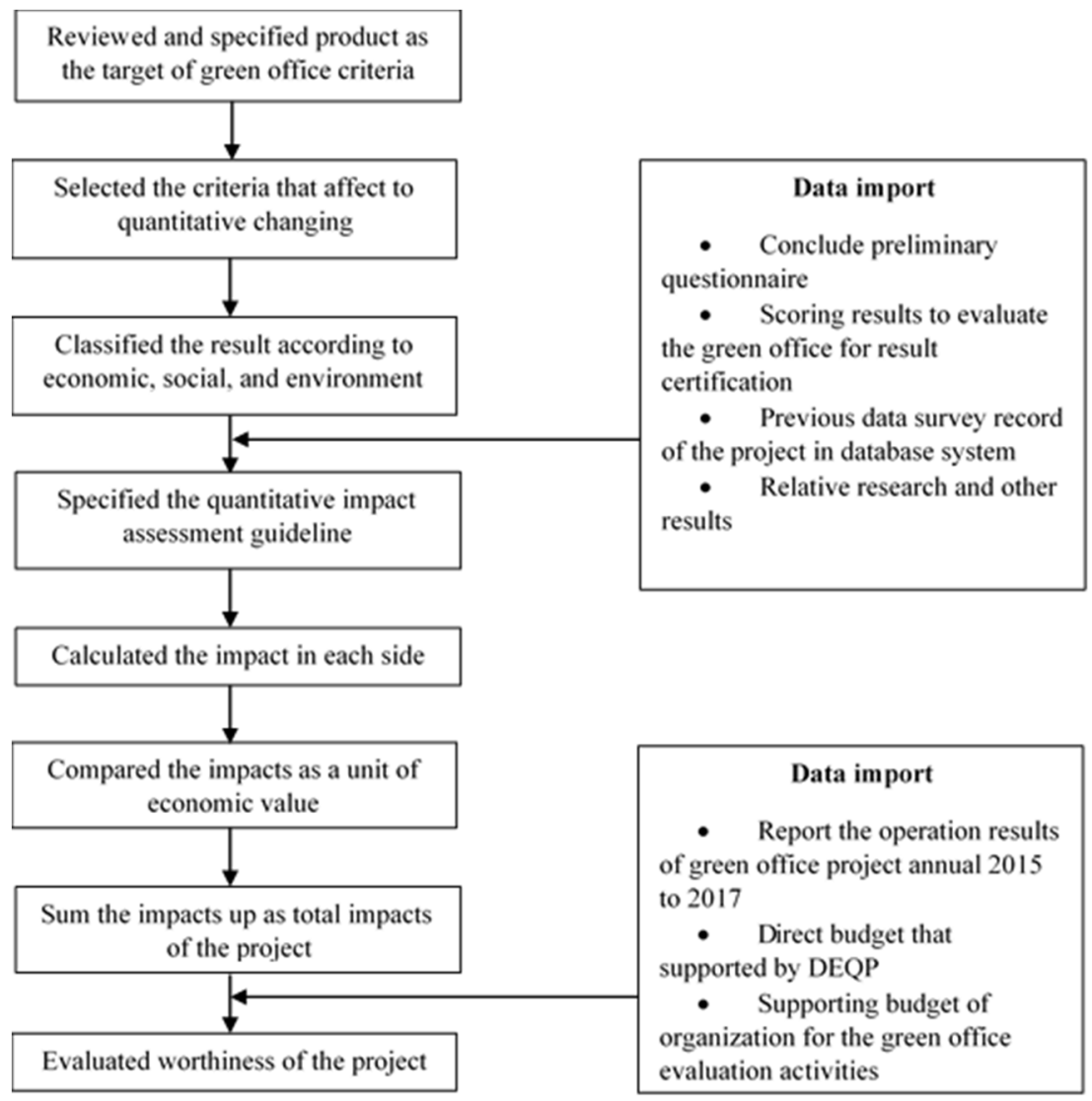

Figure 1. The guidelines for impact assessment and qualifying status of green office project's budget

\section{Economic, Social, and Environmental impact assessment}

Impact assessment of the green office project provides comments in the resulting form of the evaluated activities of green office operation of the participating offices under the supervision and criteria laid down by DEQP. The impact analysis covered both direct and indirect, and quantitative and qualitative. The analysis was done from hypothesis testing, calculation from previous data and measurement of the indicators for evaluation in the form of financial proxy monetization, such as replacement cost of greenhouse gas reduction by multiplying with carbon credit cost and quantity of reduced amount of greenhouse gases The result helps overall society by reducing the budget allocation for greenhouse gas management cost, Financial proxy monetization are illustrated in Table 5 . The financial proxy may have some uncertainty in the information depending on the variability of the value per unit and quantitative differences that affect the value. Therefore, the average financial proxy was classified as a low and high value from reviewing various sources of calculated data that were considered as economic impact and presented as data intervals. 
Table 5. Financial proxy and data background of each item

\begin{tabular}{|c|c|c|c|c|c|}
\hline Item & unit & mean & $\min$ & $\max$ & remarks \\
\hline The average price of water supply & $\mathrm{m}^{3}$ & 27.50 & 21.75 & 29.75 & $\begin{array}{l}\text { The price rate of the government sector } \\
\text { and small business }\end{array}$ \\
\hline Electricity price per unit & $\mathrm{kWh}$ & 4.10 & 3.80 & 4.50 & $\begin{array}{l}\text { Estimate electricity cost of user type } 3.2 \\
\text { medium business ( } 22-33 \mathrm{~kW} \text { On-peak) }\end{array}$ \\
\hline Diesel price & Liter & 25.56 & 21.89 & 26.79 & Average fuel cost (PTT, 2017) \\
\hline Gasohol price & Liter & 26.89 & 24.78 & 27.98 & Average fuel cost (PTT, 2017) \\
\hline Paper price (A4) & Ream & 120 & 100 & 140 & Cost of A4 paper depends on the quality \\
\hline Waste management cost & $\mathrm{Kg}$ & 2 & 1 & 6 & \\
\hline Wastewater treatment cost & $\mathrm{m}^{3}$ & 4.00 & 2.00 & 6.00 & $\begin{array}{l}\text { Wastewater treatment price rate of } \\
\text { Bangkok according to the study of JICA } \\
\left(\text { office size }>100 \mathrm{~m}^{2} \text { ) }\right.\end{array}$ \\
\hline $\begin{array}{l}\text { Raw water consumption ratio per } \\
\text { water supply production }\end{array}$ & $\mathrm{m}^{3}$ & 1.44 & 1.29 & 1.55 & $\begin{array}{l}\text { Raw water per water supply production } \\
\text { include loss of water in a pumping pipe }\end{array}$ \\
\hline $\begin{array}{l}\text { Average purchase price of recycling } \\
\text { materials }\end{array}$ & $\mathrm{kg}$ & 4.5 & 3.5 & 8.95 & $\begin{array}{l}\text { purchase price of recycling materials } \\
\text { according to large enterprise }\end{array}$ \\
\hline $\begin{array}{l}\text { Price of CFO training course (half } \\
\text { course) }\end{array}$ & Half course & 5,000 & 5,000 & 5,000 & $\begin{array}{l}\text { Carbon footprint training application fee } \\
\text { of the organization by NSTDA Academy }\end{array}$ \\
\hline $\begin{array}{l}\text { Depreciation and electricity bill of air } \\
\text { purifier (Baht/ } 20 \text { staffs) }\end{array}$ & Half-year & 3,700 & 2,000 & 4,000 & $\begin{array}{l}\text { Calculate from the number of air purifier } \\
\text { for room size } 60 \mathrm{~m}^{2} \text {, medium electrical } \\
\text { power } 20 \mathrm{~W} \text {, filters }(2 \text { years })(2,500 \\
\text { Baht/sheet }) \text { air purifier } 6 \text { years old } \\
(14,000 \text { Baht })\end{array}$ \\
\hline $\begin{array}{l}\text { Training cost for general } \\
\text { environmental awareness } 1 \text { person }\end{array}$ & person & 250 & 100 & 800 & $\begin{array}{l}\text { Estimate from the budget that was used } \\
\text { for activity arrangement }\end{array}$ \\
\hline Carbon credit price of T-VERS project & $\mathrm{tCO}_{2} \mathrm{e}$ & 30 & 21 & 100 & $\begin{array}{l}\text { T-VERS Carbon credit price, } 2017 \\
\left.\text { (average } 30 \mathrm{Baht} / \mathrm{tCO}_{2} \mathrm{e}\right)\end{array}$ \\
\hline Raw water cost & $\mathrm{m}^{3}$ & 0.15 & 0.10 & 0.40 & $\begin{array}{l}\text { Raw water cost that notified to MWA } \\
\text { users }\end{array}$ \\
\hline
\end{tabular}

Note: PTT is Petroleum Thai Public Company Limited; JICA is the Japan International Cooperation Agency; NSTDA is the National Science and Technology Development Agency, and T-VERS is Thailand Voluntary Emission Reduction Program.

From the result of economic, social, and environmental evaluation, it can be seen that the appraised benefit or return in the form of money was then compared to data budget and other investments that occurred from DEQP operation and participating organizations as well as used as budget by themselves. Then, it was evaluated by the principle of benefit (B) $\operatorname{cost}(\mathrm{C})$ ratio: $\mathrm{B} / \mathrm{C}$ ratio as value of green office project by using the equation formula (1) as given below:

$$
\text { Value of Green office project }=\frac{\text { Benefit }- \text { Investment }}{\text { Investment }}
$$

The result of the evaluation of the green office project from the activity list operation of each participating office was then categorized into six green offices evaluation criteria as given in Table 1.

\section{Results and Discussion}

\section{The quantitative impact assessment result of the green office project}

Quantitative results from the activities of the office operation criteria were evaluated as shown in Table 1. The data for evaluation consists of both primary as well as secondary data. Primary data was collected through a questionnaire, while secondary data was obtained from reviewing previous data. Results of green office project 
operations were divided into impacts and those impacts were then converted into value as an improvement comment for compensation of the project with financial proxy (Table 5). The total value for compensation was 299 million Baht equal to 1.4 million Baht/office/year. And this could be divided into economic compensation, (262.5 million Baht), social compensation (28.5 million Baht), and environmental compensation (7.55 million Baht). The details are shown in Table 6.

Table 6. Summary of compensation from impact assessment of the green office project activities (2015-2017 A.D.)

\begin{tabular}{|c|c|c|c|c|c|c|c|c|}
\hline \multirow{2}{*}{ No. } & \multirow{2}{*}{ Category } & \multirow{2}{*}{ Result } & \multirow{2}{*}{$\begin{array}{l}\text { Impact } \\
\text { assessment } \\
\text { guideline }\end{array}$} & \multirow{2}{*}{$\begin{array}{l}\text { Quantitative } \\
\text { result }\end{array}$} & \multirow{2}{*}{ Unit } & \multicolumn{3}{|c|}{ Compensate (Baht) } \\
\hline & & & & & & Eco & Soc & Envi \\
\hline 1 & $\begin{array}{l}\text { Greenhouse } \\
\text { gas } \\
\text { information }\end{array}$ & $\begin{array}{l}\text { Some staff can } \\
\text { evaluate the GHG } \\
\text { emission of the } \\
\text { office }\end{array}$ & $\begin{array}{l}\text { Bring the GHG } \\
\text { quantity principle } \\
\text { for a calculation } \\
\text { to apply for } \\
\text { determining the } \\
\text { GHG reduction } \\
\text { measure }\end{array}$ & 207 & person & -- & $1,035,000$ & -- \\
\hline 2 & $\begin{array}{l}\text { Campaign and } \\
\text { publicize the } \\
\text { staff }\end{array}$ & $\begin{array}{l}\text { Staffs have } \\
\text { awareness and } \\
\text { participate in } \\
\text { environmental } \\
\text { management }\end{array}$ & $\begin{array}{l}\text { Staffs are } \\
\text { continuously } \\
\text { educated to have } \\
\text { environmental } \\
\text { awareness, } \\
\text { leading to } \\
\text { individual } \\
\text { behavior changes }\end{array}$ & 54,980 & person & -- & $27,490,473$ & -- \\
\hline 3 & Water usage & $\begin{array}{l}\text { Water usage is } \\
\text { decreased }\end{array}$ & $\begin{array}{l}\text { Water bill } \\
\text { decrease }\end{array}$ & 640,247 & $\mathrm{~m}^{3}$ & $17,606,786$ & -- & -- \\
\hline 4 & Water usage & $\begin{array}{l}\text { Water usage is } \\
\text { decreased }\end{array}$ & $\begin{array}{l}\text { GHG emission } \\
\text { from water usage } \\
\text { decreased }\end{array}$ & 513 & $\mathrm{tCO}_{2} \mathrm{e}$ & -- & -- & 15,377 \\
\hline 5 & Water usage & $\begin{array}{l}\text { The working } \\
\text { group analyzed } \\
\text { the water usage } \\
\text { patterns and set } \\
\text { appropriate saving } \\
\text { measures. }\end{array}$ & $\begin{array}{l}\text { Reduce water } \\
\text { usage }\end{array}$ & 923,236 & $\mathrm{~m}^{3}$ & -- & -- & 138,485 \\
\hline 6 & energy usage & $\begin{array}{l}\text { Energy usage } \\
\text { decrease }\end{array}$ & $\begin{array}{l}\text { Electricity bill } \\
\text { decrease }\end{array}$ & $49,351,000$ & $\mathrm{kWh}$ & $202,338,907$ & -- & -- \\
\hline 7 & energy usage & $\begin{array}{l}\text { Energy usage } \\
\text { decrease }\end{array}$ & $\begin{array}{l}\text { GHG emission } \\
\text { from electrical } \\
\text { production } \\
\text { decrease }\end{array}$ & 30,100 & $\mathrm{tCO}_{2} \mathrm{e}$ & -- & -- & 902,086 \\
\hline 8 & energy usage & $\begin{array}{l}\text { Fuel oil } \\
\text { consumption } \\
\text { decrease }\end{array}$ & $\begin{array}{l}\text { Fuel value } \\
\text { decrease }\end{array}$ & 503,000 & Liter & $12,855,696$ & -- & -- \\
\hline 9 & energy usage & $\begin{array}{l}\text { Diesel } \\
\text { consumption } \\
\text { decrease }\end{array}$ & $\begin{array}{l}\text { GHG emission } \\
\text { from fuel } \\
\text { consumption } \\
\text { decrease }\end{array}$ & 1,381 & $\mathrm{tCO}_{2} \mathrm{e}$ & -- & -- & 41,419 \\
\hline 10 & energy usage & $\begin{array}{l}\text { Gasohol } \\
\text { consumption } \\
\text { decrease }\end{array}$ & $\begin{array}{l}\text { Fuel value } \\
\text { decrease }\end{array}$ & 6,680 & Liter & 179,693 & -- & -- \\
\hline 11 & energy usage & $\begin{array}{l}\text { Gasohol and } \\
\text { other fuel } \\
\text { consumption } \\
\text { decrease }\end{array}$ & $\begin{array}{l}\text { GHG emission } \\
\text { from fuel } \\
\text { consumption } \\
\text { decrease }\end{array}$ & 15.2 & $\mathrm{tCO}_{2} \mathrm{e}$ & -- & -- & 456 \\
\hline
\end{tabular}




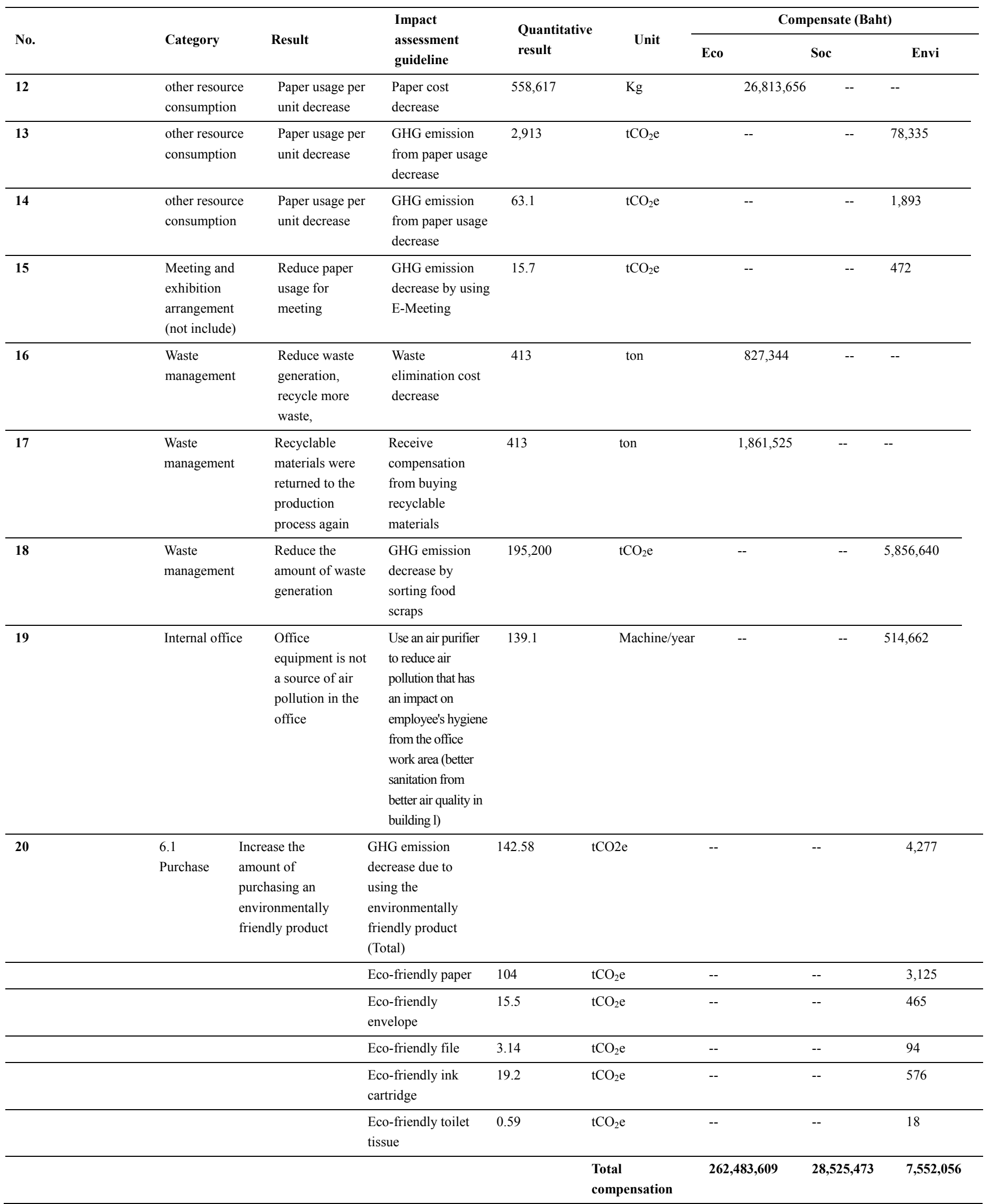

Note: Eco is Economic; Soc is Social, and Envi is Environmental. 
Activities operation under the environmentally friendly consumption and production support project, G-Green had two major steps of operation consisting of given knowledge and suggestion as well as G-Green criteria evaluation by the audit committee of DEQP (DEQP, 2019b) who support all of the budgets for operation. The budget was divided into 1) Training for auditing the green office and register for audit committee of the green office project; 2) organization of meeting for audit committee 3 ) budget for an advisor to provide recommendation and to proceed for improvement as the green office criteria; and 4) budget for auditing participating office including the budget for auditing cost that was supported by Provincial Electricity Authority (PEA). From in-depth interviewing, it was found that each office has at least a responsible person and there is a meeting for the committee about relative criteria in each topic. The committee has approximately 10 persons and counts the average of a working day as 30 days/person/office throughout the green office project (since they have applied in the project until they received certification).

The total operating budget for the green office project is approximately 5.1 million Baht divided into 3 years operation (2015-2107 A.D.), 15.3 million Baht, or equivalent to 72,440 Baht/office.

However, equipment investment which replaced the old and equipment with low efficiency, office materials that were used in the green office activities, including additional expenditure cost in green office project management cost, was not included as an investment in this assessment. For quality calculation, the investment cost budget of the green office project is compared with the Benefit-Cost Ratio according to equation 1, the obtained calculated result was 18.5 and the average value ranges from 15.6-22.6. If electricity cost is not included, then there is a decrease in the value of cost, and if paper usage increases, it was found that the compensation increases to 69.4 million Baht, and the value of the green office budget was 3.54.

For the score of satisfaction evaluation result of operators and administrators in the operation, benefits, and satisfaction of the green office operation steps are illustrated in Table 7, 8, and 9, respectively.

Table 7. Evaluation of satisfaction result of operators in green office operation steps

\begin{tabular}{llll}
\hline \multicolumn{1}{c}{ The green office operation steps } & \multicolumn{3}{c}{ Satisfaction Level (\%) } \\
\cline { 2 - 4 } & More & Medium & Low \\
\hline 1. Publicize, invite, and recruit any office to participate in the project & 47.95 & $\underline{50.68}$ & 1.37 \\
2. Office send the document through preliminary self-assessment & 58.90 & 39.73 & 1.37 \\
3. Office join to green office training & 56.16 & 38.36 & 5.48 \\
4 Visit and recommend and improvement as green office criteria & 61.64 & 31.51 & $\underline{6.85}$ \\
5. Green office evaluation by area/national committee & 72.60 & 24.66 & 2.74 \\
6. National green office auditors give a certificate as per the evaluation result & $\underline{79.45}$ & 17.81 & 1.37 \\
7. The evaluation concluded and give the award to the office that has passed the & 78.08 & 19.18 & 2.74 \\
green office evaluation test & 58.90 & 35.62 & 5.48 \\
8. Appropriateness of project duration & & & \\
\hline
\end{tabular}

Table 8. The satisfaction evaluation result of operators in the benefit of the green office project

\begin{tabular}{llll}
\hline \multicolumn{1}{c}{ The green office operation steps } & \multicolumn{3}{c}{ Satisfaction Level (\%) } \\
\cline { 2 - 4 } & More & Medium & Low \\
\hline $\begin{array}{l}\text { - Staffs have knowledge, understanding, and see the importance of green office } \\
\text { operation }\end{array}$ & $\underline{86.30}$ & 12.33 & 1.37 \\
- Staffs have changed their behavior after participating in the project & 76.71 & 23.29 & 0.00 \\
- Increase in work efficiency & 68.49 & 30.14 & 1.37 \\
- Cost and resources usage in office decrease after participating in the project & 63.01 & $\underline{34.25}$ & 2.74 \\
- Promote the quality of life of the employee & 80.82 & 17.81 & 1.37 \\
- The office continuously operates activities according to green office guideline in & 72.60 & 23.29 & $\underline{5.48}$ \\
both present and future decades & & & \\
- There should be an agency that continuously collects green office improvement \\
operation data
\end{tabular}


Table 9. The satisfaction evaluation result of administrators in the green office project operation

\begin{tabular}{|c|c|c|c|}
\hline \multirow[t]{2}{*}{ The green office operation steps } & \multicolumn{3}{|c|}{ Satisfaction Level (\%) } \\
\hline & High & Medium & Low \\
\hline 1. Received the advantage of green office operation in your office & 90.41 & 6.85 & 0.00 \\
\hline 2. The green office certification result that your office has received & 89.04 & 8.22 & 0.00 \\
\hline 3. Continuously have office improvement policy according to green office & 84.93 & 12.33 & 0.00 \\
\hline 4. Desire to renew or enhance the green office certification & 68.49 & $\underline{17.81}$ & 9.59 \\
\hline $\begin{array}{l}\text { 5. There should be an agency that continuously collects green office improvement } \\
\text { operation data }\end{array}$ & 83.56 & 13.70 & 0.00 \\
\hline
\end{tabular}

The result from 73 respondents' agencies through a preliminary questionnaire and in-depth interviewing from 25 agencies found that all of the agencies had continuously operated the green office project by policy determination and appointed a working group. Besides, there was communication for awareness and improvement through training as well as publicity obtained from various media. A publicity campaign was created in the form of a publicized board, green awareness, green meeting, creating activities, adopting and using resources saving measure, especially electricity and water by reducing the usage of paper, ink, energy, and other office resources and at the same time reducing the cost of the office's operation while reducing waste generation, proper utilization and sorting of generated waste as: general, recycle, and hazardous waste. Moreover, there was environmental and safety management in the office through green procurement (using equipment with Green label or Eco-label) according to DEQP guideline (Aroonsrimorakot, 2018; TGO, 2020).

The obtained information obtained from a preliminary questionnaire and in-depth interviewing were brought to evaluate the green office project's operations in terms of economic, social, and environmental impacts. The analysis and evaluation of the green office project are important as it recommends green office project's operations even in the future green offices, which is consistent with nine targets of United Nations SDGs, namely target 6, 7, $8,9,11,12,13,15$, and 17 .

\section{Conclusion}

The green office was operated by DEQP during 2015-2017with a budget of 15.28 million Baht, which concludes that it can create a valuable impact as 299 million Baht or equivalent valuable cost of the green office budget with benefit-cost ratio $=18.5$ times, as evaluated from operation activities criteria of the project, by consideration of the benefit of the project, consisting of 20 activities. The operating budget is separated into 3 sides, consisting of economic (energy cost and direct and indirect resources $=89 \%$ ), social (awareness and knowledge for behavioral adjustment of staff $=9 \%$ ), and environmental (estimate as environmental impact that is decreased $=2 \%$ ). The detail ratio compositions by each side are illustrated in Figure 2.

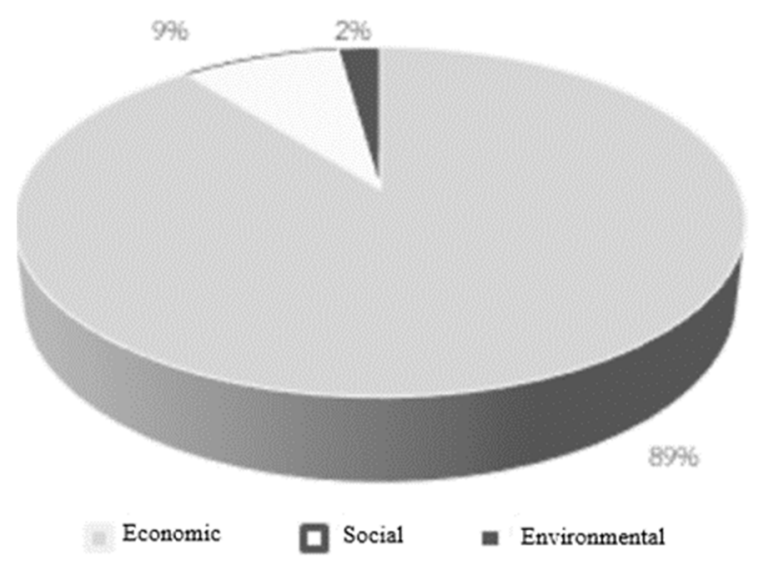

Figure 2. Economic, social, and environmental composition by ratio 
From the above result, it can be concluded that a high proportion of energy and resources expenses used in office operation decreases. This has been due to the indirect cost of each office that has been reduced by adopting cost reduction measures and supporting through various government sectors with continuous operation. Such steps are considered necessary from energy cost ratio and resource usage that decreases from a comparison of the pre-post result of green office operation. The overall analysis found a reduction in usage of energy and major resources in the office. So, in the end, it can be concluded that such steps can reduce approximately $15 \%$ by separating into items as Electricity (17\% decreasing or benefit 202,338,907 Baht), Diesel fuel $(8.4 \%$ decreasing or benefit $12,855,696$ Baht), Gasohol fuel (6.1\% decreasing or benefit 6,682 Baht), Water supply ( $16 \%$ decreasing or benefit 17,606,786 Baht), and Paper (44\% decreasing or benefit 558,617 Baht) respectively. Concerning satisfaction with green office projection operation, the study concluded with the following as:

- most participating agencies ( $79.45 \%)$ have high overall satisfaction on evaluation results of national auditors;

- most participating agencies have high satisfaction to benefit provided to staffs in terms of knowledge, understanding, and observation of the importance of green office operation (86.63\%);

- most administrators of agencies have more satisfaction to the advantage of green office operation in their office $(90.41 \%)$

\section{Acknowledgments}

The authors express gratefulness to all participating agencies and operating administrators for providing data and other valuable information and also for extending cooperation while undergoing the evaluation process of the research study. The authors are obliged to the Department of Environmental Quality Promotion (DEQP) for supporting this research project.

\section{References}

Aroonsrimorakot, S. (2018). Green Office Management Standard at Mahidol University, Thailand. Pertanika Journal of Social Sciences \& Humanities, 26(4), 2505-2521.

Aroonsrimorakot, S., \& Phuynongpho, S. (2017). Factors affecting the water usage performance of the standard application of green office in Thailand. Journal of Thai Interdisciplinary Research, 12(2), 24-30.

Aroonsrimorakot, S., \& Sarapirom, K. (2020). The development of green office standards: Thailand initiative. Interdisciplinary Research Review, 15(2), 8-18.

Aroonsrimorakot, S., Laiphrakpam, M., \& Korattana, C. (2019). Green office, its features, and importance for sustainable environmental management: A comparative review in search of similarities and differences. Journal of Thai Interdisciplinary Research, 14(5), 31-38.

Aroonsrimorakot, S., Phuynongpho, S., \& Athirot, S. (2019). Factors affecting the performance of standard application and indicator for greenhouse gas emission in green office, Thailand. Journal of Thai Interdisciplinary Research, 14(1), 60-65.

Bangkok Post. (2019). Time to take smog seriously. Retrieved form https://www.bangkokpost.com/opinion/opinion/1760549/time-to-take-smog-seriously

Burch S. (2009). In pursuit of resilient, low carbon communities: an examination of barriers to action in three Canadian cities. Energy Policy, 38(12), 7575-85. https://doi.org/10.1016/j.enpol.2009.06.070

Chowdhury, A. H., Mohammad, N., Haque, M. R. U., \& Hossain, T. (2014). Developing 3Rs (Reduce, Reuse, and Recycle) strategy for waste management in the urban areas of Bangladesh: Socioeconomic and climate adoption mitigation option. IOSR Journal of Environmental Science, Toxicology, and Food Technology (IOSR-JESTFT), 8(5), 9-18. https://doi.org/10.9790/2402-08510918

DEQP. (2018). Green office project. Retrieved from https://www.nmu.ac.th/th/wpcontent/uploads/2018/08/Green-Office-Standard-Greenofficeproject.pdf

DEQP. (2019a). Green Office development guideline. Retrieved from https://www.deqp.go.th/media/880107/gocriteria2019.pdf

DEQP. (2019b). G-green award. Retrieved from http://www.datacenter.deqp.go.th/service-portal/ggreen/thailandggreenaward2019/

Hong Kong Green Building Council. (2016). Hong Kong Green Office Guide. Retrieved from https://www.hkgbc.org.hk/eng/engagement/guidebooks/green-office-guide/index.jsp.

Opoku, A., \& Ahmed, V. (2013). Understanding sustainability: a view from intra-organizational leadership within 
UK construction organizations. International Journal of Architecture, Engineering and Construction, 2(2), 133-143. https://doi.org/10.7492/IJAEC.2013.012

Scafetta, N. (2010). Climate change and its causes, a discussion about some key issues. arXiv preprint arXiv:1003.1554.

Sodangi, I. A., Izge, A. U., \& Maina, Y. T. (2011). Climate change: causes and effects on African agriculture.

TGO. (2020). Greenhouse gas mitigation mechanism. Retrieved from http://ghgreduction.tgo.or.th/t-ver.html

The World Green Building Council. (2016). Green offices that keep staff healthy and happy are improving productivity \& boosting businesses' bottom line, finds the report. Retrieved from https:/www.worldgbc.org/news-media/green-offices-keep-staff-healthy-and-happy-are-improvingproductivity-boosting-businesses

Varanavicius, V., \& Navikaite, A. (2015). Competitive advantage attainment via synergy in green offices. Journal of International Studies, 8(3), 141-151.

WCED, \& Brundtland, G. H. (1987). Our Common Future. World Commission on Environment and Development (WCED), Oxford University Press.

Wichai-utcha, N., \& Chavalparit, O. (2019). 3Rs Policy and plastic waste management in Thailand. Journal of Material Cycles and Waste Management, 21(1), 10-22. https://doi.org/10.1007/s10163-018-0781-y

World Wide Fund for Nature Finland. (2020). What is green office? Retrieved from https://wwf.fi/en/greenoffice/what-is-green-office/

World Wildlife Fund. (2010). Green Office Environmental Management System for Sustainable Organizations, Achievements, and Activities in 2010. (p.5). Retrieved from https://wwf.fi/mediabank/1414.pdf

\section{Copyrights}

Copyright for this article is retained by the author(s), with first publication rights granted to the journal.

This is an open-access article distributed under the terms and conditions of the Creative Commons Attribution license (http://creativecommons.org/licenses/by/4.0/). 